\title{
Establishment of ruminal enzyme activities and fermentation capacity in dairy calves from birth through weaning
}

\author{
M. Rey, ${ }^{\star} \dagger$ F. Enjalbert, ${ }^{*} \dagger^{1}$ and V. Monteils ${ }^{*} \dagger^{2}$ \\ *INRA, UMR 1289 TANDEM, Tissus Animaux, Nutrition, Digestion, Ecosystème et Métabolisme, F-31326 Castanet-Tolosan, France \\ †Université de Toulouse, INPT-ENSAT, INP-ENVT, UMR 1289 TANDEM, F-31326 Castanet-Tolosan, France
}

\begin{abstract}
The objectives of this study were to characterize the establishment of ruminal fermentation and enzymatic activities in dairy calves from birth to weaning (d 83). Six Holstein calves, immediately separated from their mother at birth, were fed colostrum for $3 \mathrm{~d}$ after birth, and thereafter milk replacer, starter pelleted concentrate, and hay until d 83 of age. Ruminal samples were collected from each calf every day for the first $10 \mathrm{~d}$, and additionally at d 12, 15, 19, 22, 26, 29, 33, 36, 40, $43,47,50,55,62,69$, and 83 . Ruminal samples were collected $1 \mathrm{~h}$ after milk feeding with a stomach tube. The $\mathrm{pH}$ and redox potential $\left(\mathrm{E}_{h}\right)$ were immediately measured. Samples were kept for further determination of ammonia nitrogen $\left(\mathrm{NH}_{3}-\mathrm{N}\right)$ and volatile fatty acid (VFA) concentrations, and xylanase, amylase, urease, and protease activities. Ruminal $\mathrm{pH}$ averaged 6.69, 5.82 , and 6.34 , from d 1 to 9 , d 10 to 40 , and d 43 to 83 of age, respectively. At first day of life, the ruminal $\mathrm{E}_{h}$ value was positive $(+224 \mathrm{mV})$. From $\mathrm{d} 2$ to 9 , d 10 to 40 , and d 43 to 83 of age, ruminal $\mathrm{E}_{h}$ averaged $-164,-115$, and $-141 \mathrm{mV}$, respectively. From $\mathrm{d} 1$ to 3 , d 4 to 22 , and d 26 to 83 of age, $\mathrm{NH}_{3}-\mathrm{N}$ concentration averaged 60.1, 179.8, and $58.2 \mathrm{mg} / \mathrm{L}$, respectively. No VFA were detected in ruminal samples collected on d 1 of life of calves. From d 2 to 10 and d 12 to 83 of age, ruminal total VFA concentration averaged 19.5 and $84.4 \mathrm{~m} M$, respectively. Neither ruminal xylanase or amylase activities were observed at $\mathrm{d} 1$ of age. From d 5 to 15 and d 19 to 83 of age, the xylanase activity averaged 182.2 and $62.4 \mu \mathrm{mol}$ of sugar released per hour per gram of ruminal content dry matter (DM), respectively. From d 5 to 83 of age, the amylase activity reached $35.4 \mu \mathrm{mol}$ of sugar released per hour per gram of ruminal content DM. The ruminal ureolytic activity was observed with an average value of $6.9 \mu \mathrm{g}$ of $\mathrm{NH}_{3}-\mathrm{N}$ released per minute per gram of ruminal content DM
\end{abstract}

\footnotetext{
Received September 5, 2011.

Accepted November 13, 2011.

${ }^{1}$ Corresponding author: f.enjalbert@envt.fr

${ }^{2}$ Present address: VetAgro Sup Campus agronomique, Unité de recherches Elevage et Production de Ruminants, F-63370 Lempdes, France.
}

over the 83-d experimental period. From d 1 to 4 and d 5 to 83 of age, the proteolytic activity was 8.2 and 27.9 optical density units per hour per gram of ruminal content DM, respectively. The fermentative and enzymatic activities were rapidly established in the rumen from $d$ 2 after birth. Most parameters did not evolve further after 1 mo of age.

Key words: dairy calf, ruminal $\mathrm{pH}$ and redox potential, fermentation, enzymatic activity

\section{INTRODUCTION}

From birth to 3 wk of age, young ruminants are described as preruminants, because rumen is considered as not anatomically and physiologically mature (Warner, 1956; Bryant et al., 1958; Tamate et al., 1962), with a small volume relative to the whole digestive tract compared with adults, and the mucosa is not developed (Smith, 1961). In preruminants, the first functional compartment of the digestive system is the abomasum, which plays a major function in the digestion of milk (Longenbach and Heinrichs, 1998). The establishment of a digestive activity in the rumen needs water, a dietary substrate, and microbial activity. Passage of liquid into the abomasum of young ruminants is controlled by the esophageal groove (Ørskov et al., 1970). Wise and Anderson (1939) observed that milk consumption induces the closure of the esophageal groove in calves and that milk directly passes to the abomasum. In calves drinking only milk and water in a bucket from d 20 to weaning, Wise and Anderson (1939) showed that up to $40 \%$ of milk and about $95 \%$ of water intake can enter the rumen. Consequently, milk could constitute the first substrate for fermentation in the rumen. Bryant et al. (1958) and Bryant and Small (1960) showed that a rapid set up of the microbiota in the rumen of calves takes place during the first week of life. In lambs, Fonty et al. (1987) went a step further, showing a temporal and sequential establishment of microbiota and ruminal functions during the first $10 \mathrm{~d}$ after birth.

In commercial dairy herds, when solid food intake increases with age of calves, milk allowance is gradually 
decreased until weaning. Suárez et al. (2006) showed, in preweaned dairy calves, that solid feed intake stimulates microbial proliferation and VFA production in the rumen, which reflects the capacity of ruminal microbiota to degrade feedstuffs. Anderson et al. (1987), Beharka et al. (1991), and Chaucheyras-Durand and Fonty (2002) observed an increase of fermentative activity in the rumen of young calves and lambs up to 1 mo of age. The main enzymatic activities (fibrolytic, amylolytic, proteolytic, and ureolytic) of ruminal microbiota have been observed in the rumen as soon as d 4 (Sahoo et al., 2005) or 10 (Kmet et al., 1986b) of age. However, as far as we are aware, the establishment of ruminal activity immediately after birth has not been investigated. Moreover, from the first week of life, Chaucheyras-Durand and Fonty (2002) measured a strongly negative redox potential in the rumen of lambs, which indicated that the ruminal environment already is a high-reducing milieu, as observed in dairy cows (Marden et al., 2008; Julien et al., 2010) and in heifers (Monteils et al., 2011). However, oxido-reducing status of the rumen in newborn calves at birth still remains unknown.

The aim of the present study was to characterize the establishment of fermentative ruminal functions in the preweaning period of dairy calves. The main physicochemical and fermentation parameters of the rumen and the main enzymatic activities were measured from birth to weaning day at $\mathrm{d} 83$ of age with special focus between $\mathrm{d} 1$ to 10 after birth to ascertain when the rumen becomes functional in calves.

\section{MATERIALS AND METHODS}

All animal housing and handling procedures were in accordance with the guidelines for animal research of the French Ministry of Agriculture (Anonymous, 1988).

\section{Animals, Experimental Design, and Diets}

The study was carried out on 5 male and 1 female Holstein calves from birth (d 1) to d 83 (before weaning). Calves were immediately separated from their mothers at birth and weighed (mean initial $\mathrm{BW}=39.4$ $\pm 1.7 \mathrm{~kg}$ ). They were housed in a nursery, in individual pens $(1.05 \times 2.30 \mathrm{~m}$, bedded with straw $)$ to avoid direct contact between calves and mature animals. The first meal after birth was given less than $2 \mathrm{~h}$ after birth with $2 \mathrm{~L}$ of frozen-thawed colostrum. Until d 3, each calf was offered twice a day a meal of $1.5 \mathrm{~L}$ of frozen-thawed colostrum $(\mathrm{CP}=33.7 \pm 7.1 \%$ of $\mathrm{DM})$ distributed in a separate bucket at 0900 and $1700 \mathrm{~h}$.

From d 4 to 83 , all calves were fed milk replacer: $620 \mathrm{~g} / \mathrm{d}$ from d 4 to $14,750 \mathrm{~g}$ from d 15 to $21,880 \mathrm{~g}$ from d 22 to $42,750 \mathrm{~g}$ from d 43 to $49,500 \mathrm{~g}$ from d 50 to $56,370 \mathrm{~g}$ from d 57 to 70 , and $240 \mathrm{~g}$ from d 71 to 83 . The milk replacer was reconstituted at $124 \mathrm{~g}$ of milk powder/L of warm water $\left(38^{\circ} \mathrm{C}\right)$. In addition, all calves were allocated daily a pelleted starter concentrate and low-quality meadow hay at first, second, and third month after birth: 0.2 and $0.06 \mathrm{~kg}, 1.2$ and 0.2 $\mathrm{kg}$, and 2.9 and $0.4 \mathrm{~kg}$, respectively. Feeds were distributed individually daily, in separate buckets, in 2 equal meals at 0800 and $1600 \mathrm{~h}$ for milk replacer, and at 0900 and $1700 \mathrm{~h}$ for hay and starter concentrate. Each calf had available clean water controlled daily. All amounts of milk replacer, starter concentrate and hay offered and refused were recorded individually daily. Chemical composition of milk replacer, hay and concentrate (Table 1) was determined from samples taken every 15 d during the experimental period.

\section{Sampling and Measurements}

Samples of whole ruminal contents were obtained from each calf every day between d 1 and 10 and additionally at d 12, 15, 19, 22, 26, 29, 33, 36, 40, 43, $47,50,55,62,69$, and 83 after birth. Rumen samples (approximately $500 \mathrm{~mL}$ ) were collected via a stomach tube (i.d. $13 \mathrm{~mm}$ ), sterilized before use with $2 \%$ Steranios (Centravet 803910; Centravet SA, Lapalisse, France; disinfection of surgical and medical equipment, endoscopy equipment, and heat-sensitive instruments with a bactericide, fungicide, sporicide, and virucide), $1 \mathrm{~h}$ after the milk morning meal and just before the distribution of hay and starter concentrate. It was separated in 2 equal fractions. The first one was used to fill completely a glass-collecting vessel to limit the contact of ruminal content with air. The $\mathrm{pH}$, redox potential $\left(\mathbf{E}_{h}\right)$, and temperature measurements were carried out using 3 electrodes. A glass $\mathrm{pH}$ electrode (Unitrode $\mathrm{pH}$ LL, 60259100, Metrohm, Villebon-sur-Yvette, France), an $\mathrm{E}_{h}$ platinum electrode (Pt SC, 60351100, Metrohm), and a thermo-electrode (Pt 1000, 61110100, Metrohm) connected to a digital pH-meter (model 713; Metrohm AG, Herisau, Switzerland) were dipped into the vessel without any air entrance. Both $\mathrm{pH}$ and $\mathrm{E}_{h}$ values were recorded after a 20-min stabilization period as recommended by Andrade et al. (2002) in vitro and Kimsé et al. (2009) in rabbit cecum content.

A representative aliquot $(50 \mathrm{~g})$ of the second fraction was mixed with $25 \mathrm{~mL}$ of a $6.5 \mathrm{pH}$-buffer $[0.025 \mathrm{M}$, 2 -(N-morpholino)ethanesulfonic acid], stored at $-20^{\circ} \mathrm{C}$ and then quickly transferred at $-80^{\circ} \mathrm{C}$. One representative part was used for the determination of enzyme activities according to the method of Martin et al. (1994) and the other part was used to determinate the ruminal DM content $\left(48 \mathrm{~h}\right.$ at $\left.104^{\circ} \mathrm{C}\right)$. 
Table 1. Chemical composition of milk replacer, starter concentrate, and hay fed to calves from d 4 to 83

\begin{tabular}{lccc}
\hline & \multicolumn{2}{c}{ Feed ingredient } \\
\cline { 2 - 4 } Composition & $\begin{array}{c}\text { Milk } \\
\text { replacer, }^{1,2}\end{array}$ & $\begin{array}{c}\text { Starter } \\
\text { concentrate }^{3,4}\end{array}$ & Hay \\
\hline DM (\%) & 94.5 & 88.4 & 90.8 \\
DM basis (\%) & & & \\
OM & 93.0 & 91.6 & 92.7 \\
CP & 22.8 & 17.8 & 8.4 \\
NDF & $\mathrm{ND}^{5}$ & 21.6 & 74.5 \\
ADF & $\mathrm{ND}$ & 10.2 & 45.1 \\
Ether extract & 18.1 & 2.7 & 0.7 \\
Starch & 4.4 & 37.6 & ND \\
\hline
\end{tabular}

${ }^{1}$ Contained skim milk powder spray (50\%, DM basis), whey powder spray, vegetable oils and fats, and products and byproducts of cereal grains and fructo-oligosaccharides.

${ }^{2}$ Contained $\mathrm{Cu}(10 \mathrm{mg} / \mathrm{kg}), \mathrm{Fe}(45 \mathrm{mg} / \mathrm{kg})$, butylated hydroxytoluene, vitamin A $(25,000 \mathrm{IU} / \mathrm{kg})$, vitamin $\mathrm{D}_{3}$ $(5,000 \mathrm{IU} / \mathrm{kg})$, vitamin $\mathrm{E}(100 \mathrm{mg} / \mathrm{kg})$, vitamin $\mathrm{B}_{1}(10 \mathrm{mg} / \mathrm{kg})$, vitamin $\mathrm{B}_{2}(8 \mathrm{mg} / \mathrm{kg})$, vitamin $\mathrm{C}(200 \mathrm{mg} /$ $\mathrm{kg})$, and vitamin $\mathrm{K}_{3}(4 \mathrm{mg} / \mathrm{kg})$.

${ }^{3}$ On a DM basis (\%): 31 barley, 15 wheat, 13 husked sunflower cake, 10 corn, 10 maize germ meal, 7 sunflower cake, 5 wheat middlings, and traces of sugar cane molasses and rapeseed meal.

${ }^{4}$ Contained vitamin $\mathrm{A}(7,000 \mathrm{IU} / \mathrm{kg})$, vitamin $\mathrm{D}_{3}(1,500 \mathrm{IU} / \mathrm{kg})$, vitamin $\mathrm{E}(20 \mathrm{mg} / \mathrm{kg})$, and vitamin $\mathrm{B}_{1}(10$ $\mathrm{mg} / \mathrm{kg})$.

${ }^{5} \mathrm{ND}=$ not determined.

The remaining fraction (approximately $200 \mathrm{~mL}$ ) was strained through a metal sieve (1.6-mm mesh) and 8 $\mathrm{mL}$ of the filtrate was sampled with $10 \%$ of mercuric chloride $(2 \% \mathrm{wt} / \mathrm{vol})$ and stored at $-20^{\circ} \mathrm{C}$ for subsequent VFA and ammonia nitrogen $\left(\mathrm{NH}_{3}-\mathrm{N}\right)$ concentration determinations.

\section{Chemical Analysis}

The concentrations of VFA were determined using the gas chromatographic method of Playne (1985), modified by Marden et al. (2008). The determination of $\mathrm{NH}_{3}-\mathrm{N}$ was based on the modified Berthelot reaction with the Skalar Method, followed by a colorimetric test (Krom, 1980).

\section{Determination of Enzymatic Activities}

Samples of rumen content were thawed at room temperature and submitted to ultrasonic disintegration at $4^{\circ} \mathrm{C}$ ( 4 cycles of $30 \mathrm{~s}$ separated by $30 \mathrm{~s}$ of rest) then centrifuged $\left(20,000 \times g\right.$ for $15 \mathrm{~min}$ at $\left.4^{\circ} \mathrm{C}\right)$ to separate cellular debris and enzymes (Martin and MichaletDoreau, 1995). Only the recovered supernatant was used to assay the enzymatic activities (enzymatic sample), and was frozen at $-80^{\circ} \mathrm{C}$ until enzymatic activity measurements.

Xylanase and amylase activities ( $\mu$ mol of sugar released/h per gram of total ruminal content DM) were determined according to Martin et al. (1994) by measuring the release of reducing sugars from substrates (xylan and starch, Sigma X-0502 and S-2004, respectively; Sigma, Saint Quentin Fallavier, France) during $1 \mathrm{~h}$ at $39^{\circ} \mathrm{C}$ with $1 \mathrm{~mL}$ of substrate $(2 \mathrm{mg} / \mathrm{mL}$ in 2 - $(N$-morpholino)ethanesulfonic acid (MES) buffer, $\mathrm{pH}$ $6.5,0.0025 M)$ and $0.1 \mathrm{~mL}$ of enzymatic sample. The mixture was incubated for $7 \mathrm{~min}$ at $100^{\circ} \mathrm{C}$ to stop the hydrolysis reaction. Reducing sugars were quantified by spectrophotometry at $410 \mathrm{~nm}$ after reaction with 4-hydroxybenzoic acid hydrazide (Lever, 1977).

Ureolytic activity ( $\mu \mathrm{g}$ of $\mathrm{NH}_{3}-\mathrm{N}$ released/min per gram of total ruminal content DM) was determined by measuring the production of $\mathrm{NH}_{3}-\mathrm{N}$ after 15 min of incubation at $37^{\circ} \mathrm{C}$ of $0.125 \mathrm{~mL}$ of enzymatic sample, $0.125 \mathrm{~mL}$ of urea $(15 \mathrm{mg}$ of urea Sigma U-5378 and $8 \mathrm{mg}$ of EDTA Sigma E-9884 in $25 \mathrm{~mL}$ of phosphate buffer), and $0.25 \mathrm{~mL}$ of phosphate buffer. The reaction was stopped by adding $2.5 \mathrm{~mL}$ of phenol solution $(1 \mathrm{~g}$ of phenol and $5 \mathrm{mg}$ of $\mathrm{Na}_{2}\left[\mathrm{Fe}(\mathrm{CN})_{5} \mathrm{NO}\right] \cdot 2 \mathrm{H}_{2} \mathrm{O}$ in $100 \mathrm{~mL}$ of distilled water) and $2.5 \mathrm{~mL}$ of $\mathrm{NaOH}$ solution $(0.5 \mathrm{~g}$ of $\mathrm{NaOH}$ and $0.84 \mathrm{~mL}$ of $\mathrm{NaClO}$ in $100 \mathrm{~mL}$ of distilled water). The measurement of $\mathrm{NH}_{3}-\mathrm{N}$ released was performed by spectrophotometry at $665 \mathrm{~nm}$ (Moharrery and Das, 2001).

The proteolytic activity [optical density (at $420 \mathrm{~nm}$ ) units/h per gram of total ruminal content $D M]$ was measured after hydrolysis of $0.5 \mathrm{~mL}$ of azocasein $(2 \%$ wt/vol in $0.1 M$ citrate phosphate buffer, $\mathrm{pH} 6.8$ ) with $0.4 \mathrm{~mL}$ of enzymatic sample in $1 \mathrm{~h}$ at $39^{\circ} \mathrm{C}$. The reaction was stopped by adding $0.5 \mathrm{~mL}$ of trichloroacetic acid (15\% wt/vol). The hydrolysis of azocasein (Sigma A-2765) released an azo group, which induced a coloration measured by spectrophotometry at $420 \mathrm{~nm}$ (Eun and Beauchemin, 2005). 


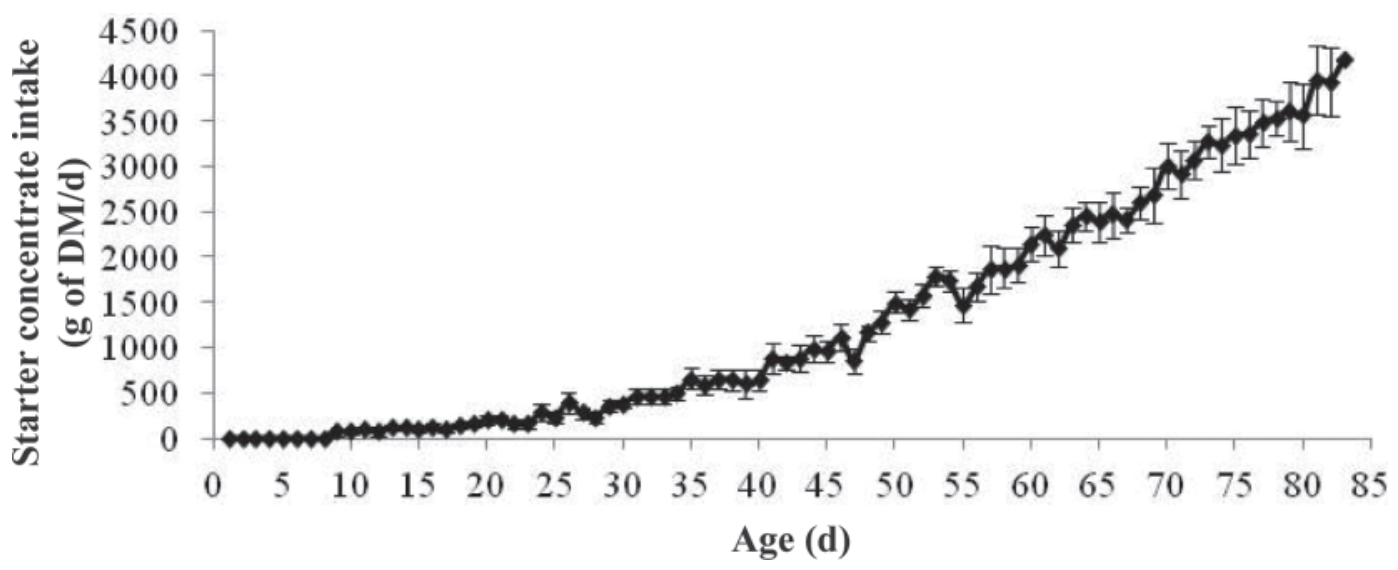

Figure 1. Kinetics of starter concentrates intake ( $\mathrm{g}$ of $\mathrm{DM} / \mathrm{d}$ ) of preweaned calves. Vertical bars show standard errors.

\section{Calculations}

Because an $\mathrm{Ag}-\mathrm{AgCl}$ reference electrode was used to measure ruminal $\mathrm{E}_{h}$, all differences of potential were corrected using the formula $\mathrm{E}_{h}=\mathrm{E}_{0}+\mathrm{C}$, where $\mathrm{E}_{0}$ is the potential of the platinum electrode and $\mathrm{C}$ is the potential of the $\mathrm{Ag}-\mathrm{AgCl}$ reference electrode compared with the Standard Hydrogen Electrode (i.e., + $199 \mathrm{mV}$ at $\left.39^{\circ} \mathrm{C}\right)$.

\section{Statistical Analysis}

All data were analyzed using the SYSTAT software (SYSTAT 9; SPSS Inc., Chicago, IL) and were reported as mean values with standard error. The ruminal physicochemical parameters, fermentation parameters, enzymatic activities, and kinetics of feed intake were analyzed as repeated measures, reporting the withinsubjects effect of age and the linear, quadratic, and cubic components of age effect. Effects were declared significant at $P \leq 0.05$.

The TREES module of SYSTAT was used to generate age classes for all parameters of this study. When the TREES module put forward only 2 classes, the TREES module was restarted on each of the 2 classes to tentatively separate subperiods.

\section{RESULTS}

\section{Feed Intake}

Calves drank daily the total quantity of milk replacer they were allocated. From d 9 of age, on average, calves began to consume starter concentrate. The intake of starter concentrate could be divided into 3 age classes explaining $83 \%$ of total variance. From d 4 to 51 , d 52 to 69 , and d 70 to 83 of age, starter concentrate
DMI was $424 \pm 76,2,096 \pm 190$, and $3,450 \pm 263 \mathrm{~g} / \mathrm{d}$, respectively (Figure 1).

From d 4 of age, calves began to consume hay. The intake of hay could be divided into 4 age-classes explaining $52 \%$ of total variance. From d 4 to 30 , d 31 to 57 , d 58 to 75 , and d 76 to 83 of age, hay DMI was 56 $\pm 19,195 \pm 50,360 \pm 66$, and $564 \pm 105 \mathrm{~g}$ of $\mathrm{DM} / \mathrm{d}$, respectively (Figure 2).

\section{Physicochemical and Fermentation Parameters}

An effect of age was observed on daily ruminal $\mathrm{pH}$ $(P<0.001$, Table 2$)$. The evolution of ruminal $\mathrm{pH}$ with the age of calves (Figure 3a) could be divided into 3 age classes explaining $31.8 \%$ of the total variance (Figure 4). The 3 age classes observed were from d 1 to 9 , from d 10 to 40 , and from d 43 to 83 .

An effect of age was observed on ruminal $\mathrm{E}_{h}(P<$ 0.001 ; Table 2). The ruminal $\mathrm{E}_{h}$ values recorded at $\mathrm{d} 1$ of life were positive, averaging $+224 \pm 34 \mathrm{mV}$ (Figure $3 \mathrm{~b})$. After that, ruminal $\mathrm{E}_{h}$ values decreased drastically to become negative. The evolution of ruminal $\mathrm{E}_{h}$ between d 2 and 83 could be divided into 3 classes explaining $20.9 \%$ of the total variance (Figure 4 ). The 3 age classes observed were from d 2 to 9 , from d 10 to 40 , and from d 43 to 83 , where the ruminal $\mathrm{E}_{h}$ stabilized to an average of $-141 \pm 20 \mathrm{mV}$.

An effect of age $(P<0.001$; Table 2$)$ was observed on ruminal $\mathrm{NH}_{3}-\mathrm{N}$ concentration, which averaged 16.9 $\pm 4.2 \mathrm{mg} / \mathrm{L}$ at $\mathrm{d} 1$ of birth (Figure 5). The evolution of ruminal $\mathrm{NH}_{3}-\mathrm{N}$ concentration between $\mathrm{d} 1$ and 83 could be divided into 3 classes explaining $42.4 \%$ of the total variance (Figure 4 ). The 3 age classes determined were from d 1 to 3 , from d 4 to 22, and from d 26 to 83 where $\mathrm{NH}_{3}-\mathrm{N}$ stabilized at an average value of 58.2 $\pm 17.2 \mathrm{mg} / \mathrm{L}$. 


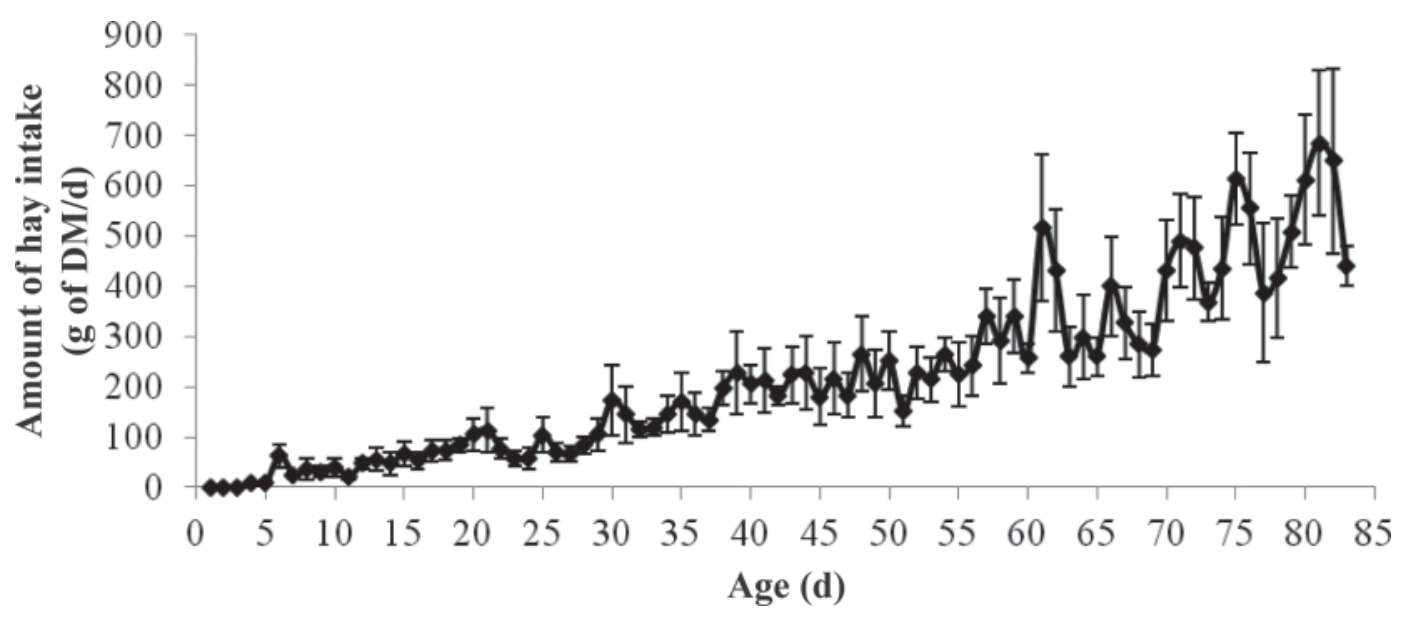

Figure 2. Kinetics of hay intake ( $\mathrm{g}$ of $\mathrm{DM} / \mathrm{d}$ ) of preweaned calves. Vertical bars show standard errors.

Through the 83-d period an effect of age $(P<0.001$, Table 2) on total VFA concentration was observed. No VFA were detected in ruminal samples collected at $\mathrm{d} 1$ of life of calves (Figure 6a). The evolution of total VFA in ruminal content with calf age could be divided into 2 classes explaining $61.1 \%$ of the total variance (Figure 4). The 2 age classes were before d 10 of age and from d 12 to 83 . The evolution of ruminal acetate (C2) and butyrate (C4) concentrations (Figure 6b) could be divided into 2 classes explaining 60.1 and $43.4 \%$ of the total variance, respectively (Figure 4). The 2 age classes were before d 9 and between d 10 and 83 . The evolution of ruminal propionate (C3) concentration
(Figure 6b) could be divided into 2 classes (before $\mathrm{d} 12$ after birth and between d 15 and 83) explaining 58.6\% of the total variance (Figure 4). The evolution of the C2/C3 ratio (Figure 6c) could be divided into 3 classes explaining $41.9 \%$ of the total variance (Figure 4 ). The 3 age classes determined were d 2, d 3 to 10 , and d 12 to 83 .

\section{Ruminal Enzymatic Activities}

An effect of age (Table 2) was observed on ruminal xylanase $(P<0.001)$, amylase $(P<0.001)$, and ureolytic $(P<0.05)$ activities over the 83 -d experimental

Table 2. Average ruminal physicochemical and fermentation parameters, and enzymatic activities in calves during the total preweaning period

\begin{tabular}{|c|c|c|c|c|c|c|}
\hline \multirow[b]{2}{*}{ Item } & \multirow[b]{2}{*}{ Mean } & \multirow[b]{2}{*}{ SEM } & \multicolumn{4}{|c|}{$P$-value ${ }^{1}$} \\
\hline & & & $\mathrm{A}$ & $\mathrm{L}$ & $\mathrm{Q}$ & $\mathrm{C}$ \\
\hline \multicolumn{7}{|l|}{ Physicochemical parameter } \\
\hline $\mathrm{pH}$ & 6.3 & 0.05 & $<0.001$ & 0.46 & 0.002 & 0.04 \\
\hline $\mathrm{E}_{h}^{2}(\mathrm{mV})$ & -138 & 3.1 & $<0.001$ & 0.22 & 0.56 & 0.26 \\
\hline \multicolumn{7}{|l|}{ Fermentation parameter } \\
\hline $\mathrm{NH}_{3}-\mathrm{N}(\mathrm{mg} / \mathrm{L})$ & 116.4 & 5.3 & $<0.001$ & $<0.001$ & 0.72 & 0.03 \\
\hline Total VFA $(\mathrm{m} M)$ & 61.0 & 2.0 & $<0.001$ & $<0.001$ & $<0.001$ & 0.34 \\
\hline Acetate $(\mathrm{m} M)$ & 33.5 & 0.9 & $<0.001$ & 0.001 & 0.002 & 0.16 \\
\hline Propionate $(\mathrm{m} M)$ & 21.8 & 0.9 & $<0.001$ & $<0.001$ & $<0.001$ & 0.71 \\
\hline Butyrate $(\mathrm{m} M)$ & 3.6 & 0.2 & $<0.001$ & 0.01 & $<0.001$ & 0.15 \\
\hline Acetate:propionate ratio & 3.1 & 0.4 & $<0.001$ & 0.03 & 0.04 & 0.08 \\
\hline \multicolumn{7}{|l|}{ Enzymatic activity } \\
\hline Xylanase $^{3}$ & 86.0 & 7.8 & $<0.001$ & 0.05 & 0.50 & 0.01 \\
\hline Amylase $^{3}$ & 30.5 & 1.7 & $<0.001$ & 0.48 & 0.27 & 0.01 \\
\hline Ureolytic $^{4}$ & 6.9 & 0.7 & 0.046 & 0.62 & 0.04 & 0.10 \\
\hline Proteolytic $^{5}$ & 24.9 & 1.0 & $<0.001$ & 0.60 & $<0.001$ & 0.02 \\
\hline
\end{tabular}

${ }^{1} \mathrm{~A}=$ age effect; $\mathrm{L}=$ linear effect of age; $\mathrm{Q}=$ quadratic effect of age; $\mathrm{C}=$ cubic effect of age.

${ }^{2} \mathrm{E}_{h}=$ redox potential.

${ }^{3}$ Xylanase activity and amylase activity ( $\mu$ mol of reduced sugar/h per gram of ruminal content DM).

${ }^{4}$ Ureolytic activity ( $\mu \mathrm{g}$ of $\mathrm{NH}_{3}-\mathrm{N}$ released/min per gram of ruminal content $\mathrm{DM}$ ).

${ }^{5}$ Proteolytic activity (optical density units/h per gram of ruminal content DM). 
(a)

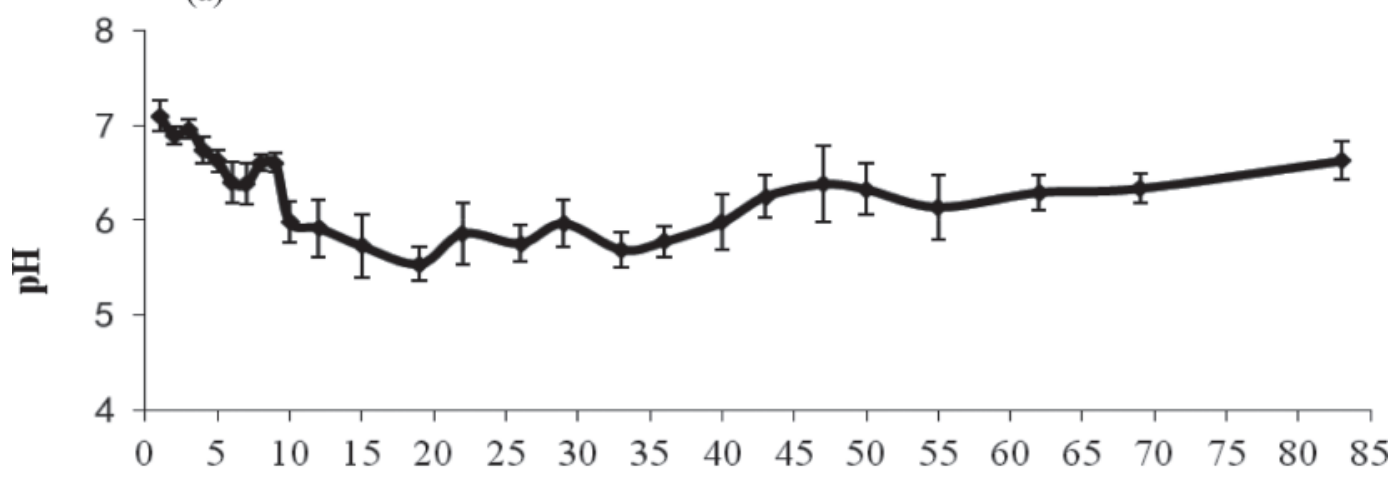

(b)

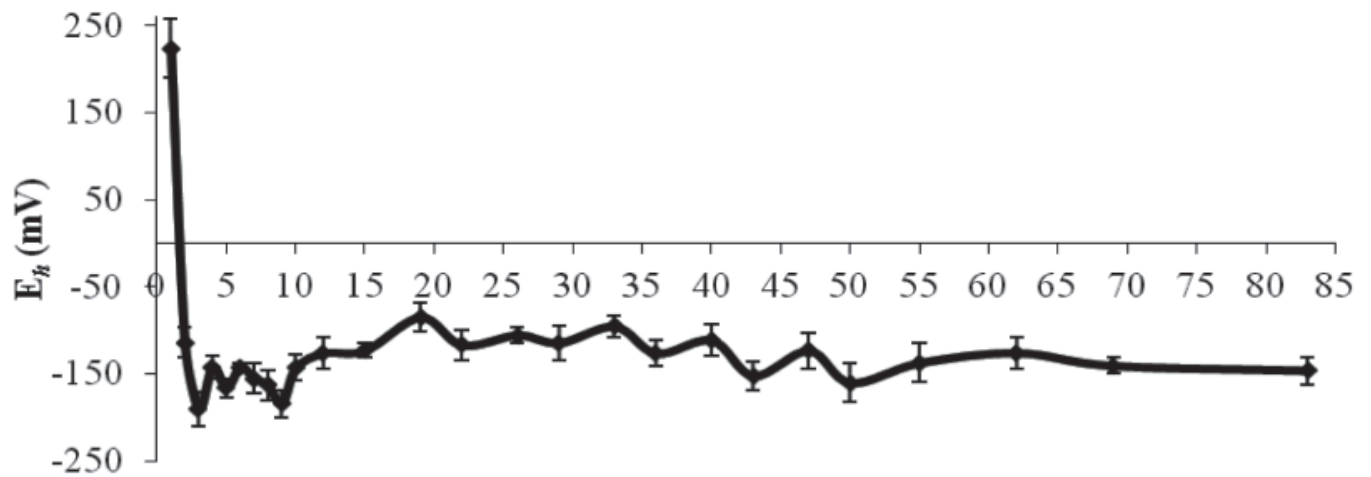

Age (d)

Figure 3. Evolution of $\mathrm{pH}(\mathrm{a})$ and redox potential $\left(\mathrm{E}_{h} ; \mathrm{b}\right)$ with the age of calves during the preweaning period. Vertical bars show standard errors.

period. No ruminal xylanase and amylase activities were observed at $\mathrm{d} 1$ of age (Figures 7 and 8).

Whereas the evolution of xylanase activity could be divided into 3 classes (between d 2 and 4, d 5 and 15 and d 19 and 83) explaining $26.1 \%$ of the total variance (Figure 4), that of amylase could be divided into 2 classes explaining $23.5 \%$ of the total variance (Figure 4): from d 2 to 4 and from d 5 to 83 . No different classes could be generated for explaining the total variance (Figure 4) of the evolution of ureolytic activity, which averaged $6.9 \pm 2.7 \mu \mathrm{g} / \mathrm{min}$ per gram of ruminal content DM (Figure 9) over the 83-d period.

An effect of age $(P<0.001$, Table 2$)$ was observed on ruminal proteolytic activity over the 83-d experimental period. The evolution of proteolytic activity (Figure 10) could be divided into 2 classes explaining $22.9 \%$ of total variance (Figure 4). The 2 age classes observed were from d 1 to 4 and from d 5 to 83 .

\section{DISCUSSION}

Figure 4 shows that, for most physicochemical studied parameters, the segmentation of the preweaning period split the subperiods around d 10 to 12 . The TREES procedure resulted in different separation of subperiods for ammonia, but a clear peak of values was observed around d 10 (Figure 5).

\section{Evolution from Birth to d 10 of Age}

Data showed that the ruminal milieu of early newborn calves (d 1) was devoid of VFA and of xylanase and amylase activities, and had very low $\mathrm{NH}_{3}-\mathrm{N}$ concentration and proteolytic activity. These observations reflected an absence of fermentative activity in the rumen and a weak capacity of enzymatic degradation at d 1 of life. Fonty et al. (1995) explained that the rumen at birth only contains saliva, mucus, desquamated epithelial cells, and a very little amount of usable energy substrate. In the present study, ruminal $\mathrm{pH}$ at $\mathrm{d} 1$ was close to neutrality $(7.10 \pm 0.13)$ and the milieu was highly oxidative with a positive $\mathrm{E}_{h}$ value of $+224 \pm 34$ $\mathrm{mV}$. The $\mathrm{E}_{h}$ value recorded agrees with the value of $+270 \mathrm{mV}$ reported by Julien et al. (2010) in a sterilized ruminal fluid from dairy cows, reflecting the oxidative status of a milieu denied of living organisms. Ruminal 


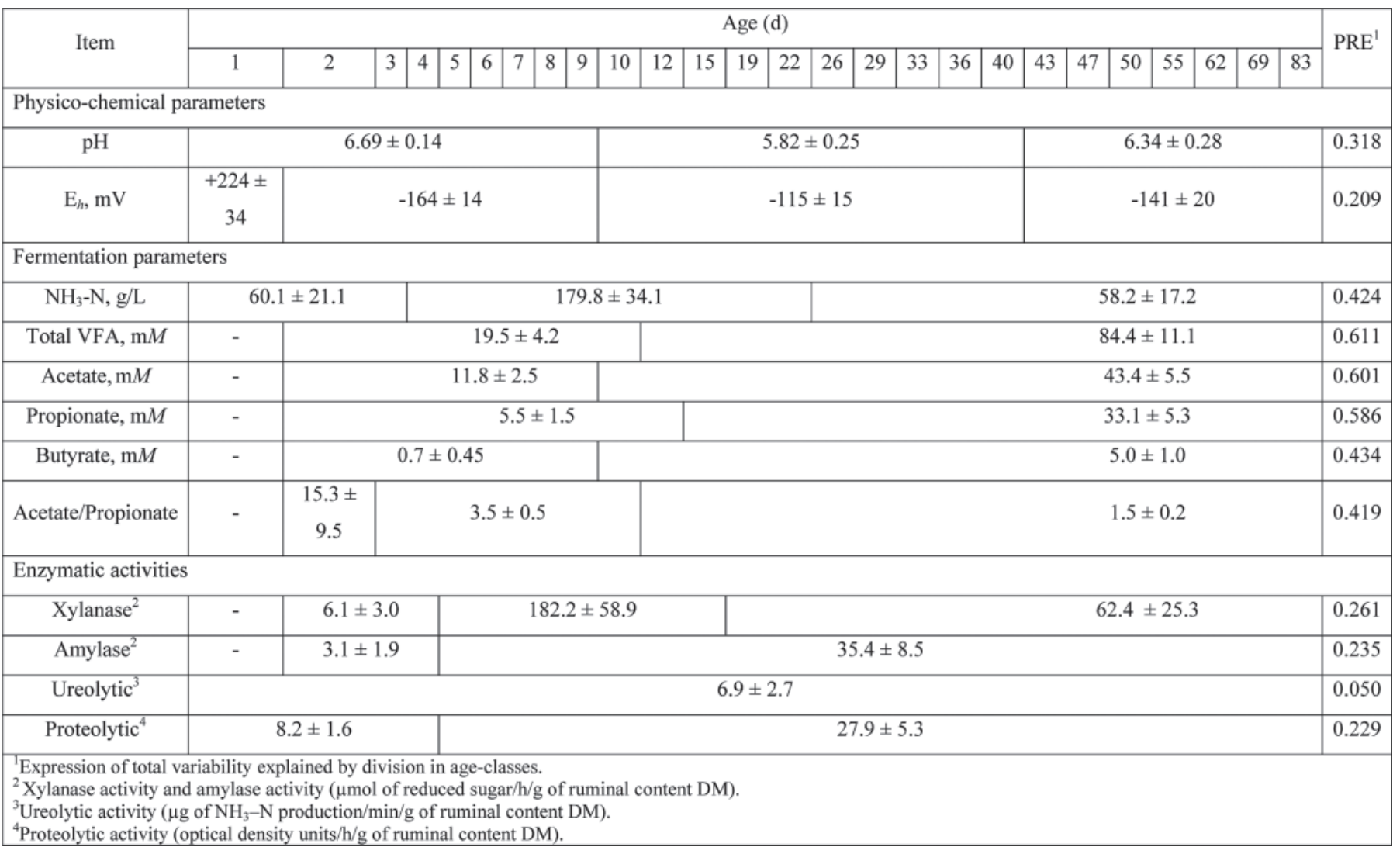

Figure 4. Age classes of ruminal physicochemical and fermentation parameters, and enzymatic activities (mean $\pm \mathrm{SD}$ ).

$\mathrm{E}_{h}$ became drastically negative $(-164 \mathrm{mV}$, on average) as soon as d 2, reaching values previously reported by Marden et al. (2008) and Julien et al. (2010) in adult dairy cows, and by Monteils et al. (2011) in heifers (i.e., between -110 and $-220 \mathrm{mV}$ according to the composition of the diet). By measuring a difference of potential, Chaucheyras-Durand and Fonty (2002) also noted an increase of reducing power in the ruminal milieu of lambs between d 2 and 10 of age. Taken together, these results suggest that the establishment and the maintenance of reducing conditions in the rumen originate from microbial activity.

The rapid change in oxido-reducing status of the rumen observed would be related to the implantation of

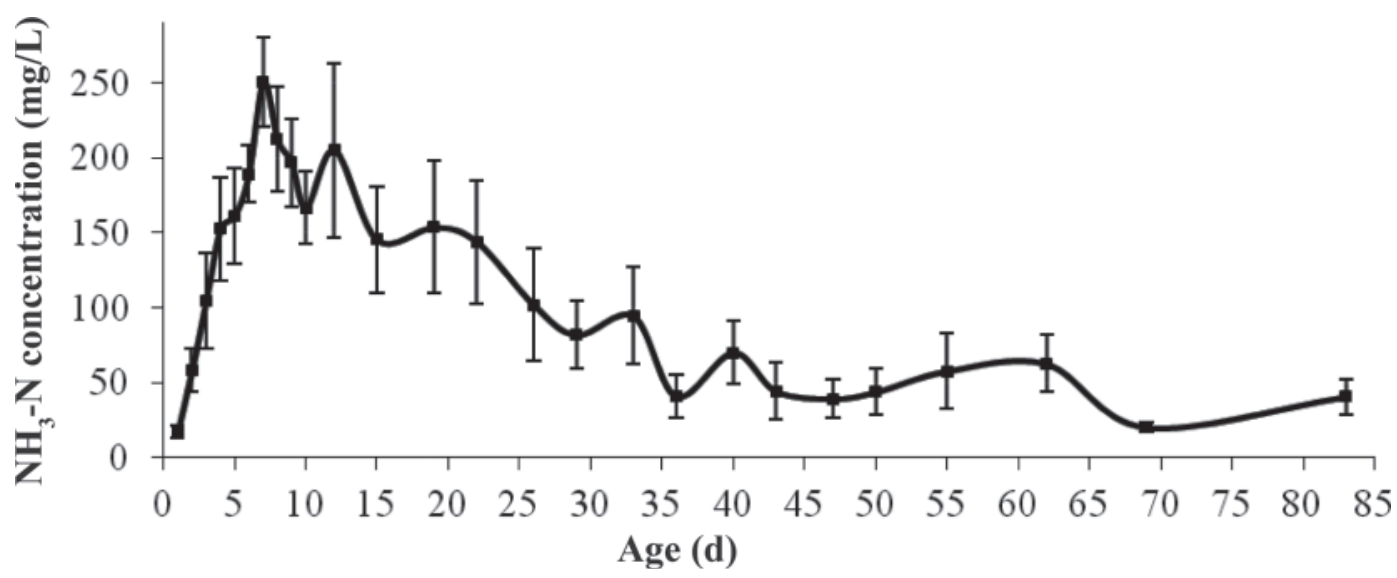

Figure 5. Evolution of ruminal $\mathrm{NH}_{3}-\mathrm{N}$ concentration with the age of calves during the preweaning period. Vertical bars show standard errors. 
(a)

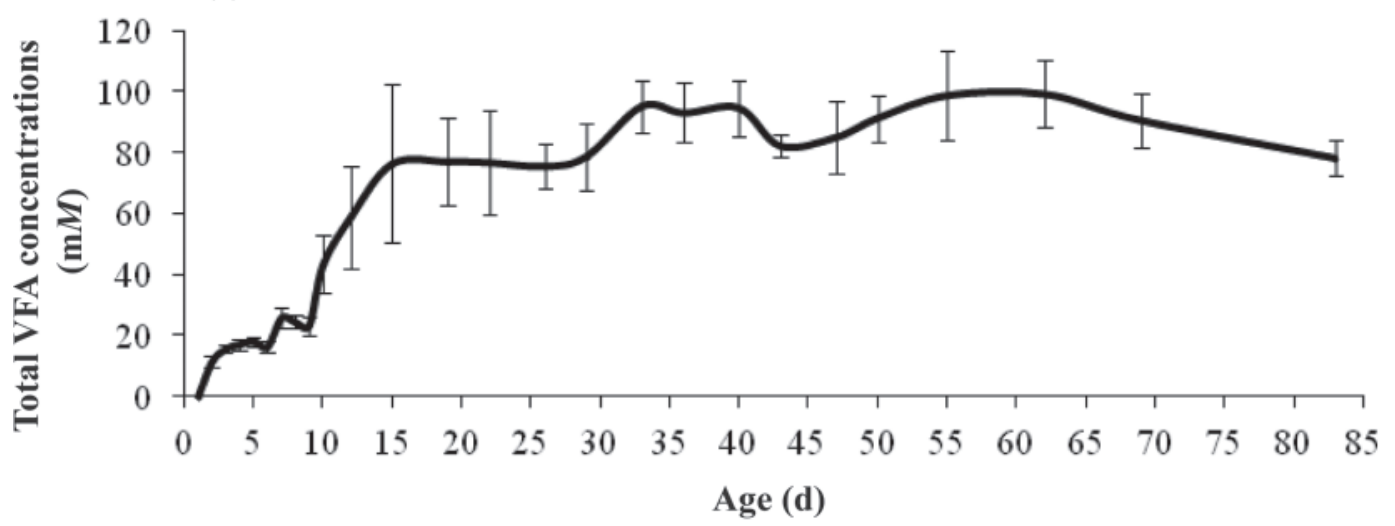

(b)

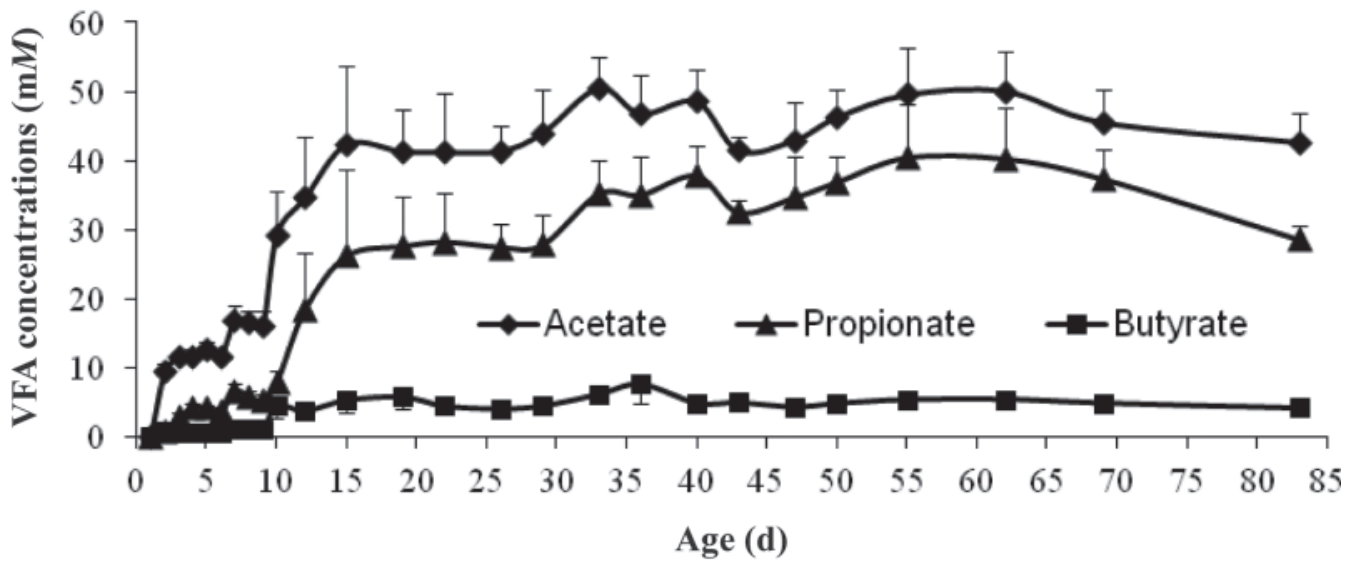

(c)

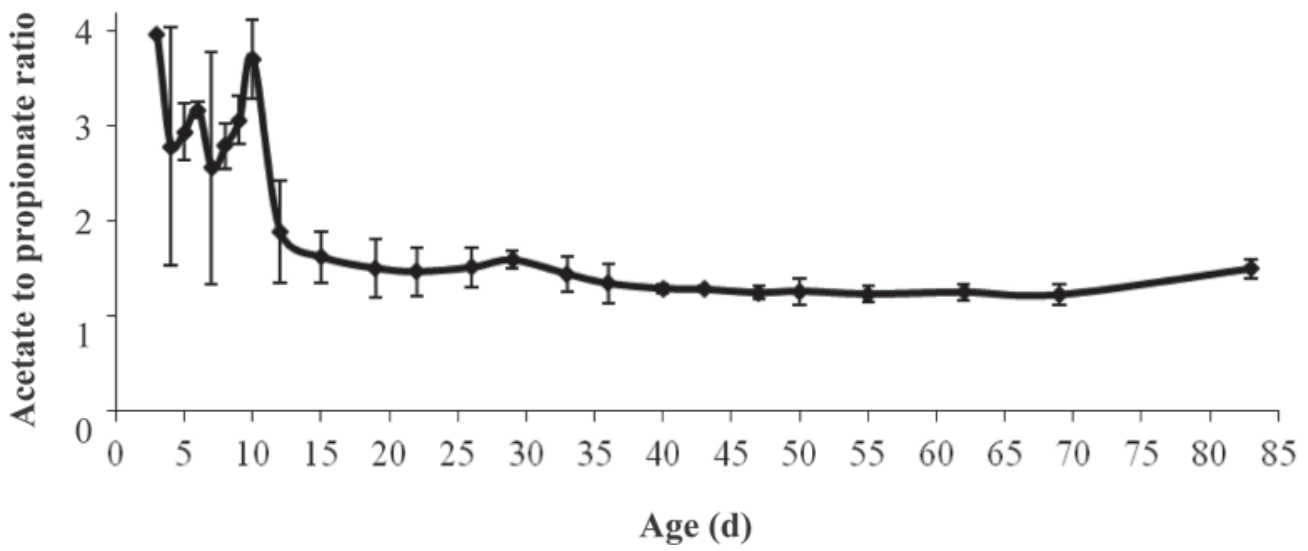

Figure 6. Evolution of total (a) and main (b) ruminal VFA concentrations, and acetate-to-propionate ratio (c) with the age of calves during the preweaning period. Vertical bars show standard errors.

ruminal microflora and is supported by earlier studies, which showed a sequential establishment of bacterial communities between d 2 and 10 of life in calves (Bryant et al., 1958; Jayne-Williams, 1979) and in lambs (Fonty et al., 1987). Facultative anaerobic bacteria, which first colonize the ruminal milieu (Fonty et al., 1987), were likely involved in oxygen consumption, leading to a more reducing environment. Subsequently, the anaerobic medium in the rumen becomes a propitious environment for the establishment of strictly an- 


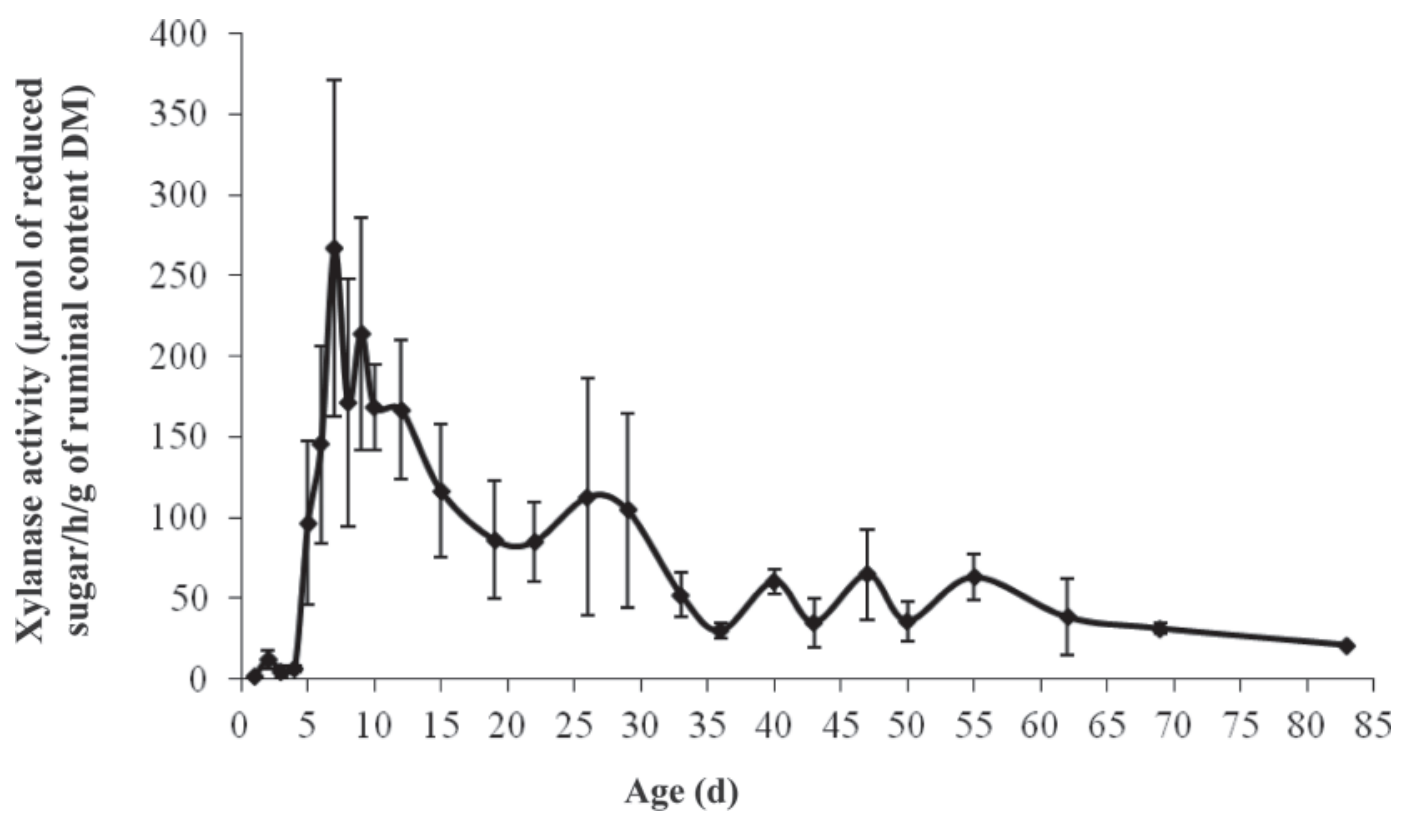

Figure 7. Evolution of ruminal xylanase activity with the age of calves during the preweaning period. Vertical bars show standard errors.

aerobic bacteria communities. Moreover, fibrolytic and amylolytic bacteria are known to establish in ruminal content before d 4 of age in lambs (Fonty et al., 1983) and calves (Anderson et al., 1987).

Results of the present study agree with all these observations because at d 2, xylanase and amylase activities were detected at a low level in ruminal con- tent. These activities increased drastically from $\mathrm{d} 4$ to reach a maximum value at $\mathrm{d} 7$ and 10 for xylanase and amylase activities, respectively, with a higher activity for xylanase $(270 \mu \mathrm{mol}$ of sugar released/h per gram of total ruminal content DM) than for amylase $(67 \mu \mathrm{mol}$ of sugar released/h per gram of total ruminal content $\mathrm{DM})$. Because during this period calves did not consume

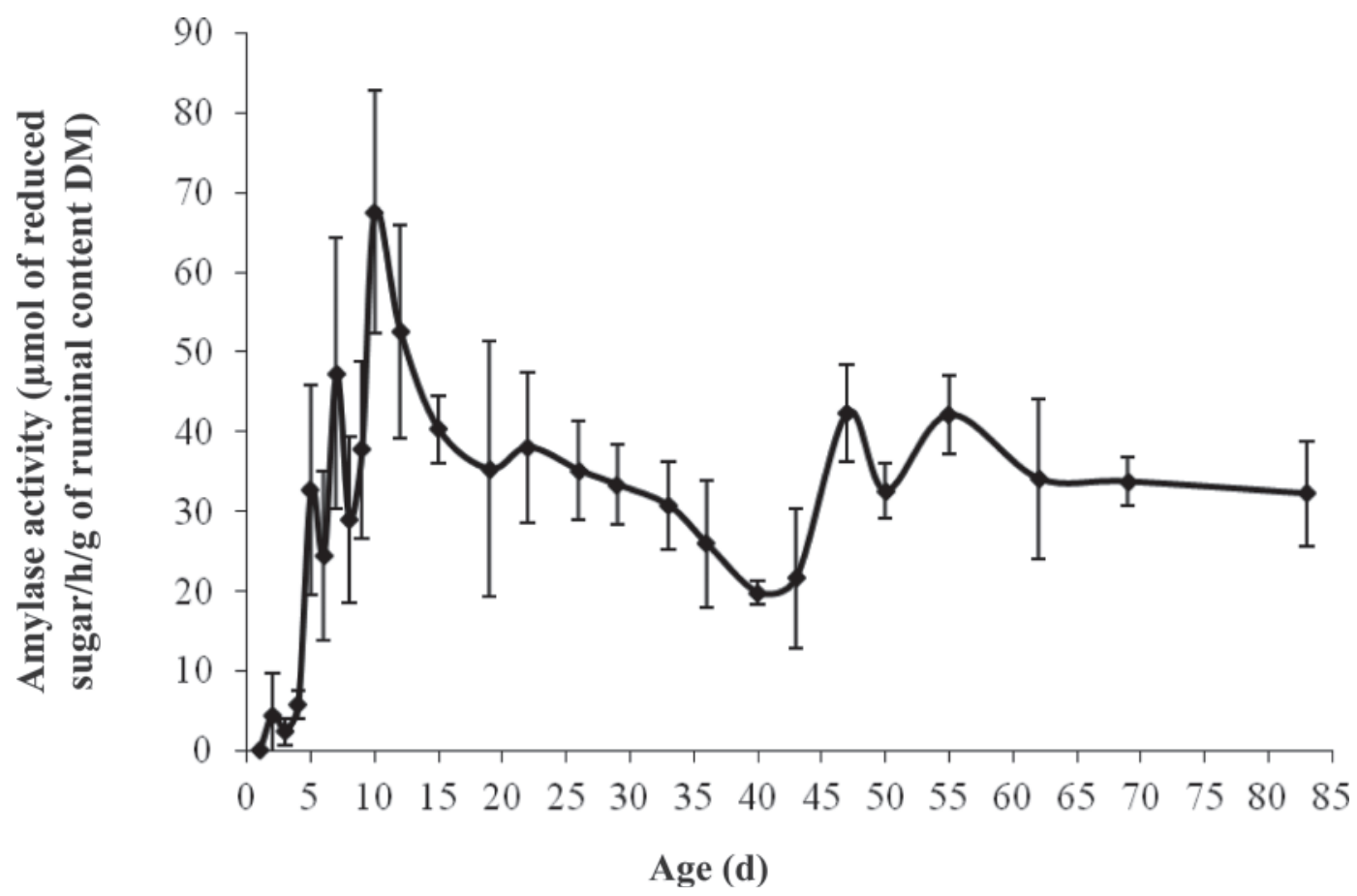

Figure 8. Evolution of ruminal amylase activity with the age of calves during the preweaning period. Vertical bars show standard errors. 


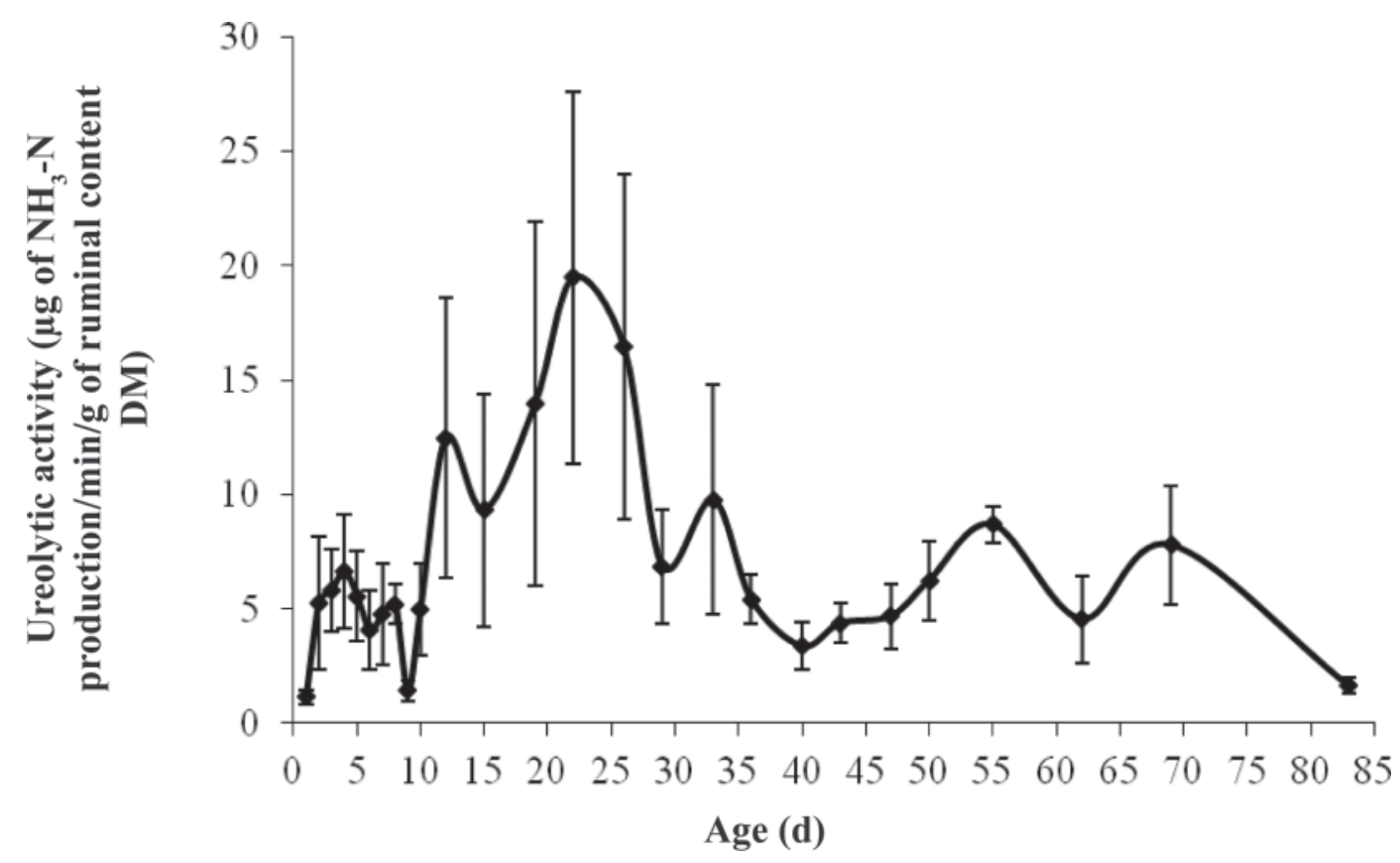

Figure 9. Evolution of ruminal ureolytic activity with the age of calves during the preweaning period. Vertical bars show standard errors.

solid food, the potential activity measured showed the existence of a degradation capacity before arrival of substrate. In the present study, $\mathrm{C} 2$ was detected at $\mathrm{d}$ 2, whereas $\mathrm{C} 3$ and $\mathrm{C} 4$ were first measured at $\mathrm{d} 3$. Between $\mathrm{d} 2$ and 10, the total VFA ruminal concentration only slightly increased, with a major proportion of $\mathrm{C} 2$ $(80 \%)$. These data are consistent with the observations of Anderson et al. (1987). This slow evolution of VFA concentration before d 10 could be associated with the very low intake of solid food by calves, in spite of xylanase and amylase activities that were, from $\mathrm{d} 5$, in the range of values observed several weeks later. This low but progressive increase in VFA concentration occurred at the same time as the drop in ruminal $\mathrm{pH}$. At this

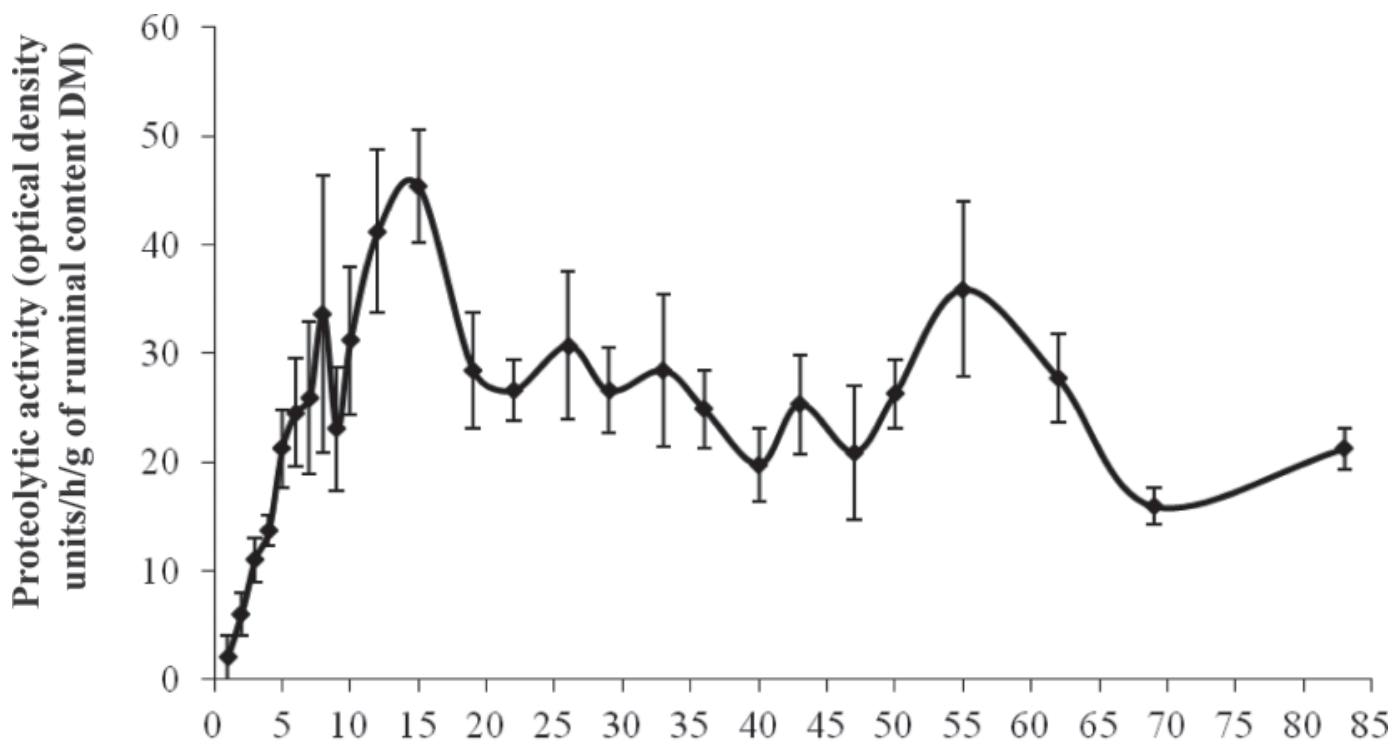

Age (d)

Figure 10. Evolution of ruminal proteolytic activity with the age of calves during the preweaning period. Vertical bars show standard errors. 
time, passage of some milk replacer into the rumen and its fermentation cannot be totally ruled out.

To our knowledge, no precise determination has been made of the times at which ureolytic and proteolytic activities take place in newborn calves. In the present study, these activities were already detected at d 1 of age. The proteolytic activity continuously increased from $\mathrm{d} 2$ to 15 . The early proteolytic activity observed could be explained by the first proteolytic bacteria colonizing the rumen in the middle of the first week of age in calves (Anderson et al., 1987). Similarly, ureolytic activity could be observed from d 2, and was slightly modified until d 10. During the first days of life, $\mathrm{NH}_{3}-\mathrm{N}$ concentration increased. This could be explained by the proteolysis of some colostrum and milk replacer reaching the rumen and (or) mucopeptides contained in the mucus-filled rumen and (or) the breakdown of desquamated epithelial cells by adherent-bacteria (Cheng et al., 1979). Ammonia absorption may also be limited in the preruminant, resulting in the observed ruminal $\mathrm{pH}$ value of 6.69 at that time. The present study is consistent with the results of previous studies (Kmet et al., 1986a,b; Sahoo et al., 2005), which showed that the main enzymatic activities (fibrolytic, amylolytic, proteolytic, and ureolytic) were observed at the end of the first week of life of calves.

\section{Evolution from d 10 of Age to Weaning}

From d 10 of age to weaning, the intake of hay and concentrate progressively increased, providing substrates to the ruminal microbiota. Between d 10 and 30 , the ruminal $\mathrm{pH}$ decreased with a time pattern that was opposite to that of total VFA content, which acidified the ruminal content. From 1 mo of age, calves consumed increasing amounts of hay (from an average of $195 \mathrm{~g}$ at $\mathrm{d} 30$ to $564 \mathrm{~g}$ of $\mathrm{DM} / \mathrm{d}$ at d 70). Intake of hay stimulated the ruminating reflex of calves and, therefore, induced salivation (Anderson et al., 1987). Saliva and its buffering action in the rumen are known to be linked with rumination, which only begins at the end of the second week of age (Swanson and Harris, 1958). This could have contributed to the increase of ruminal $\mathrm{pH}$, which reached a value higher than 6 between $\mathrm{d} 50$ and 83 . This increase of $\mathrm{pH}$ above 6 was also noted by Anderson et al. (1987) in calves at d 56 of life. The $\mathrm{E}_{h}$ value decreased from d 10 to weaning. In cows, this parameter has been shown to require a long time to evolve after a dietary change, and to remain fairly unstable (Monteils et al., 2011).

The total VFA concentration increased from $\mathrm{d} 2$ to 12 of age to reach a plateau $(84.4 \mathrm{mM})$. Similarly, Anderson et al. (1987) and Beharka et al. (1991), in calves, and Chaucheyras-Durand and Fonty (2002), in lambs, showed that from the first week of life to 1 mo of age, VFA ruminal concentration continuously increased to reach a stable value. Previous studies showed that the development of rumen papillae follows the intake of concentrate (Suárez et al., 2006) and the start of rumen fermentation (Tamate et al., 1962). Furthermore, Harrison et al. (1960) and Tamate et al. (1962) observed a lack of development of rumen papillae when calves consumed only milk between birth and 16 wk of age. The establishment of the papillae and the ruminal mucosa consecutive to the appearance of fermentation end products improves VFA absorption. Moreover, the increase of solid food intake led to an increasing ruminal volume (Tamate et al., 1962), which could have resulted in a dilution of ruminal content in the present study. The establishment of a balance between the development of the epithelium, the increasing rumen volume, the arrival of substrate via solid food intake and ruminal microbiota implantation could explain the observed stabilization of VFA concentration after 1 mo of life. In parallel, the $\mathrm{C} 2 / \mathrm{C} 3$ ratio decreased with the age of calves and reached $1.5 \pm 0.2$. This result was in accordance with the value of 1.62 determined by Sosin-Bzducha et al. (2010) in calves between d 10 and 90 of age.

Xylanase and amylase activities decreased (from $\mathrm{d}$ 7 and 20 for xylanase and amylase activities, respectively) until $1 \mathrm{mo}$ of age and remained stable thereafter. From d 10, the intake of solid diet by calves strongly increased. The ruminal volume could have increased, diluting the enzymatic activities. From d 10 of age to weaning, the proteolytic activity was fairly stable. In spite of linear, quadratic, and cubic effects of age on ureolytic activity, the TREES procedure could not separate classes, probably due to the great variability of this activity. On the contrary, Cook (1976) observed a strong increase in ureolytic activity between d 20 and 40 of age in lambs. Opposed to our observed stability of proteolytic and ureolytic activities, $\mathrm{NH}_{3}-\mathrm{N}$ concentration strongly decreased from d 10 to 35 . The decrease of $\mathrm{NH}_{3}-\mathrm{N}$ concentration observed in spite of the increasing arrival of dietary protein to the rumen could not be attributed to a severe decrease of proteolytic activity. These changes could be the consequence of an increased absorption of $\mathrm{NH}_{3}-\mathrm{N}$ permitted by the development of papillae and (or) from an increased utilization by microorganisms for proteosynthesis. A similar evolution of ruminal $\mathrm{NH}_{3}-\mathrm{N}$ between $\mathrm{d} 1$ and 3 mo after birth was previously observed in calves (Godfrey, 1961; VazquezAnon et al., 1993) and lambs (Chaucheyras-Durand and Fonty, 2002).

\section{CONCLUSIONS}

This study showed that the establishment of ruminal functions in calves is very rapid between $\mathrm{d} 1$ and 10 
after birth. The main fermentative and enzymatic activities that take place from d 2 are stabilized around 1 mo of age. The enzymatic activities were maximal between d 10 and 23 after birth and were variable until weaning. The ruminal milieu, strongly aerobic at birth, became quickly anaerobic and reducing from d 2 to 83 of age, probably reflecting the microbial activity and the dynamics of fermentation. Further work is needed 1) to identify the temporal and sequential establishment of microorganisms, and 2) to establish a relationship between the ruminal microbiota and the functions observed in this study.

\section{ACKNOWLEDGMENTS}

We thank the staff of the experimental station Domaine de Borret Poucharramet (Haute Garonne, France) for the excellent supervision of this study on calves, especially Brigitte Santacruz. We also thank Muriel Segura (UMR 1289 Tandem) for the technical assistance in the analysis of samples. We also thank the Midi-Pyrénées region for the participation in the financial support of this experiment.

\section{REFERENCES}

Anderson, K. L., T. G. Nagaraja, J. L. Morrill, T. B. Avery, S. J. Galitzer, and J. E. Boyer. 1987. Ruminal microbial development in conventionally or early-weaned calves. J. Anim. Sci. 64:12151226.

Andrade, P. V. D., S. Giger-Reverdin, and D. Sauvant. 2002. Relationship between two parameters ( $\mathrm{pH}$ and redox potential) characterizing rumen status. Influence of diets. Page 332 in Proc. 9th Rencontres Recherches Ruminants, Paris, France. Institut de l'Elevage - INRA, Paris, France

Anonymous. 1988. Arrêté du 18 avril 1988 fixant les conditions d'attribution de l'autorisation d'expérimenter. Pages 5608-5610 in Journal Officiel de la République Française. Journal Officiel, Paris, France.

Beharka, A. A., T. G. Nagaraja, and J. L. Morrill. 1991. Performance and ruminal function development of young calves fed diets with Aspergillus oryzae fermentation extract. J. Dairy Sci. 74:43264336.

Bryant, M. P., and N. Small. 1960. Observations on the ruminal microorganisms of isolated and inoculated calves. J. Dairy Sci. 43:654-667.

Bryant, M. P., N. Small, C. Bouma, and I. Robinson. 1958. Studies on the composition of the ruminal flora and fauna of young claves. J. Dairy Sci. 41:1747-1767.

Chaucheyras-Durand, F., and G. Fonty. 2002. Influence of a probiotic yeast (Saccharomyces cerevisiae CNCM I-1077) on microbial colonization and fermentation in the rumen of newborn lambs. Microb. Ecol. Health Dis. 14:30-36.

Cheng, K.-J., R. P. McCowan, and J. W. Costerton. 1979. Adherent epithelial bacteria in ruminants and their roles in digestive tract function. Am. J. Clin. Nutr. 32:139-148.

Cook, A. R. 1976. Urease activity in the rumen of sheep and the isolation of ureolytic bacteria. J. Gen. Microbiol. 92:32-48.

Eun, J. S., and K. A. Beauchemin. 2005. Effects of a proteolytic feed enzyme on intake, digestion, ruminal fermentation, and milk production. J. Dairy Sci. 88:2140-2153.
Fonty, G., P. Gouet, J.-P. Jouany, and J. Senaud. 1987. Establishment of the microflora and anaerobic fungi in the rumen of lambs. J. Gen. Microbiol. 133:1835-1843.

Fonty, G., J.-P. Jouany, E. Forano, and Ph. Gouet. 1995. L'écosystème microbien du réticulo-rumen. Pages 299-347 in Nutrition des ruminants domestiques. R. Jarrige, Y. Ruckebusch, C. Demarquilly, M.-H. Farce, and M. Journet, ed. INRA Editions, Paris, France.

Fonty, G., J.-P. Jouany, P. Thivend, Ph. Gouet, and J. Senaud. 1983. A descriptive study of rumen digestion in meroxenic lambs according to the nature and complexity of the microflora. Reprod. Nutr. Dev. 23:857-873.

Godfrey, N. W. 1961. The functional development of the calf. II. Development of rumen function in the calf. J. Agric. Sci. 54:177-183.

Harrison, H. N., R. G. Warner, E. G. Sander, and J. K. Loosli. 1960. Changes in the tissue and volume of the stomachs of calves following the removal of dry feed or consumption of inert bulk. J. Dairy Sci. 43:1301-1312.

Jayne-Williams, D. J. 1979. The bacterial flora of the rumen of healthy and bloating calves. J. Appl. Bacteriol. 47:271-284.

Julien, C. J. P. Marden, R. Moncoulon, and C. Bayourthe. 2010 Redox potential measurement: A new way to explore ruminal metabolism. J. Dairy Sci. 93(E-Suppl. 1):578. (Abstr.)

Kimsé, M., V. Monteils, C. Bayourthe, and T. Gidenne. 2009. A new method to measure the redox potential (Eh) in rabbit caecum: Relationship with $\mathrm{pH}$ and fermentation pattern. World Rabbit Sci. 17:63-70.

Kmet, V., K. Boda, P. Javorský, and R. Gibalová. 1986a. Dynamic of enzymatic activity development in the adherent rumen microflora. Arch. Anim. Nutr. 36:621-628.

Kmet, V., K. Boda, P. Javorský, and R. Nemcová. 1986b. The enzymatic activity of rumen microflora in calves. J. Anim. Physiol. Anim. Nutr. (Berl.) 56:73-77.

Krom, M. D. 1980. Spectrophotometric determination of ammonia. A study of the Berthelot reaction using salicylate and dichloroisocyanurate. Analyst (Lond.) 105:305-316.

Lever, M. 1977. Carbohydrate determination with 4-hydroxybenzoic acid hydrazide (PAHBAH): Effect of bismuth on the reaction. Anal. Biochem. 81:21-27.

Longenbach, J. I., and A. J. Heinrichs. 1998. A review of the importance and physiological role of curd formation in the abomasum of young calves. Anim. Feed Sci. Technol. 73:85-97.

Marden, J. P., C. Julien, V. Monteils, E. Auclair, R. Moncoulon, and C. Bayourthe. 2008. How does live yeast differ from sodium bicarbonate to stabilize ruminal $\mathrm{pH}$ in high-yielding dairy cows? J. Dairy Sci. 91:3528-3535.

Martin, C., and B. Michalet-Doreau. 1995. Variations in mass and enzyme activity of rumen microorganisms: Effect of barley and buffer supplements. J. Sci. Food Agric. 67:407-413.

Martin, C., A. G. Williams, and B. Michalet-Doreau. 1994. Isolation and characteristics of the protozoal and bacterial fractions from bovine ruminal contents. J. Anim. Sci. 72:2962-2968.

Moharrery, A., and T. K. Das. 2001. Correlation between microbial enzyme activities in the rumen fluid of sheep under different treatments. Reprod. Nutr. Dev. 41:513-529.

Monteils, V., M. Rey, L. Cauquil, A. Troegeler-Meynadier, M. Silberberg, and S. Combes. 2011. Random changes in the heifer rumen in bacterial community structure, physico-chemical and fermentation parameters, and in vitro fiber degradation. Livest. Sci. 141:104-112.

Ørskov, E. R., D. Benzie, and R. N. B. Kay. 1970. The effects of feeding procedure on closure of the oesophageal groove in young sheep. Br. J. Nutr. 24:785-795.

Playne, M. J. 1985. Determination of ethanol, volatile fatty acids, lactic and succinic acids in fermentation liquids by gas chromatography. J. Sci. Food Agric. 36:638-644.

Sahoo, A., D. N. Kamra, and N. N. Pathak. 2005. Pre- and postweaning attributes in faunated and ciliate-free calves fed calf starter with or without fish meal. J. Dairy Sci. 88:2027-2036. 
Smith, R. H. 1961. The development and function of the rumen in milk-fed calves. II. Effect of wood shavings in the diet. J. Agric. Sci. $56: 105-111$.

Sosin-Bzducha, E., J. Strzetelski, F. Borowiec, J. Kowalczyk, and K. Okoń. 2010. Effect of feeding ensiled maize grain on rumen development and calf rearing performance. J. Anim. Feed Sci. 19:195-210.

Suárez, B. J., C. G. Van Reenen, G. Beldman, J. van Delen, J. Dijkstra, and W. J. J. Gerrits. 2006. Effects of supplementing concentrates differing in carbohydrate composition in veal calf diets: I. Animal performance and rumen fermentation characteristics. J. Dairy Sci. 89:4365-4375.

Swanson, E. W., and J. D. Harris Jr. 1958. Development of rumination in the young calf. J. Dairy Sci. 41:1768-1776.
Tamate, H., A. D. McGilliard, N. L. Jacobson, and R. Getty. 1962. Effect of various dietaries on the anatomical development of the stomach in the calf. J. Dairy Sci. 45:408-420.

Vazquez-Anon, M., A. J. Heinrichs, J. M. Aldrich, and G. A. Varga. 1993. Postweaning age effects on rumen fermentation end-products and digesta kinetics in calves weaned at 5 weeks of age. J. Dairy Sci. 76:2742-2748.

Warner, A. C. I. 1956. Proteolysis by rumen micro-organisms. J. Gen. Microbiol. 14:749-762.

Wise, G. H., and G. W. Anderson. 1939. Factors affecting the passage of liquids into the rumen of the dairy calf. I. Method of administering liquids: Drinking from open pail versus sucking through a rubber nipple. J. Dairy Sci. 22:697-705. 